\title{
ENGAGING VOLUNTEERS FROM REGIONAL COMMUNITIES: NON-HOST CITY RESIDENT PERCEPTIONS TOWARDS A MEGA-EVENT AND THE OPPORTUNITY TO VOLUNTEER
}

\author{
SHERANNE FAIRLEY,* MARIA LOUISE CARDILLO,* AND KEVIN FILO $†$ \\ *University of Queensland Business School, University of Queensland, Brisbane, Australia \\ †Department of Tourism, Sport and Hotel Management, Griffith Business School, \\ Griffith University, Queensland, Australia
}

\begin{abstract}
Sport events can be leveraged by a number of different stakeholders. The current research positions a mega-event as a leverageable asset within a regional community outside of the host city. Specifically, this study investigated regional community (i.e., Townsville) resident perceptions of a mega-event (i.e., 2018 Commonwealth Games) to be hosted elsewhere in the state (i.e., The Gold Coast). Nonhost city resident perceptions towards the event and towards the potential of volunteering at the event were explored 4 years before the event. Data were collected through interviews and focus groups within the non-host city. The results revealed an existent rivalry between the host and non-host community, and a perceived lack of benefit to the non-host region. Further, non-host city resident perceptions towards volunteering at the event included: travel constraints, lack of awareness, volunteer packages, national pride, once in a lifetime experience, and meeting new people from overseas. The results provide implications for managers and government funders of mega-sport events to provide benefits to regional communities. Further, the results provide implications for volunteer managers at mega-sport events to engage members from regional communities through volunteering.
\end{abstract}

Key words: Resident perceptions; Mega-events; Non-host city; Regional community; Volunteers; Commonwealth Games

Introduction

Cities and nations often bid to host international sport events with the view that the event will benefit the country (Misener \& Mason, 2008). Although the majority of studies have focused on economic impact and infrastructure upgrades (Hall, 1989; Kang \& Perdue, 1994), the focus has shifted to the social benefits that the event can provide (Gursoy \& Kendall, 2006). Specifically, events have been shown to yield social and community benefits such as psychic income, which includes excitement, 
euphoria, and community pride as a result of hosting the event (Andersson, Rustad, \& Solberg, 2004; Kim \& Morrison, 2005). The social impacts, which can also include building social capital among host communities (Misener \& Mason, 2006), are often used to justify government investment (Jago, Chalip, Brown, Mules, \& Ali, 2003). Thus, resident perception studies have been highlighted as an integral component of an analysis of a mega-event (Jeong \& Faulkner, 1996).

State and national level tax dollars are often spent on the hosting of events, however the benefits are generally localized to a limited drawing radius around the event (Mules, 1998). Gratton, Shibli, and Coleman (2005) highlight that while government expenditure on an event may be good for the actual host city, it may not be the best use of public funds from a national perspective. Subsequently, there have been suggestions that efforts must be made to increase the flow of benefits to smaller regional communities (Daniels, 2007; Jones, 2005), especially given the size and scope of certain mega-events (Karadakis \& Kaplanidou, 2012). The benefits that have reached the more distant communities have been referred to as spillover effects (Deccio \& Baloglu, 2002). However, research has suggested that a more strategic approach, referred to as leveraging the event, may be useful in engaging regional communities (Kellett, Hede, \& Chalip, 2008).

Large scale events would not be possible without the assistance of a significant workforce of volunteers (Cuskelly, Hoye, \& Auld, 2006), which can equally be the foci of community development (Downward \& Ralston, 2006). Research has noted the ability of mega-events to draw volunteers from outside of the host city (Downward \& Ralston, 2005), and has indicated that individuals may travel to volunteer at sport events (Fairley, Kellett, \& Green, 2007). Therefore, one way in which nonhost communities could be involved in the event is through volunteering at the event. This study examines regional community (i.e., Townsville) resident perceptions of a mega-event (i.e., The Commonwealth Games) to be hosted elsewhere in the state (i.e., Gold Coast). In addition, the current research investigates regional community residents' perceptions of volunteering for this mega-event within the host destination.
Literature Review

\section{Resident Perceptions: A Non-Host City}

It is often postulated that community support of an event from local residents is key to the success of hosting events (Fredline, 2005; Gursoy \& Kendall, 2006). Residents may be asked to vote for and/or subsequently pay taxes that help pay for infrastructure and improvements necessary for the event (Preuss \& Solberg, 2006). Additionally, events seek to recruit and retain a large number of residents to act as volunteers (Cuskelly et al., 2006). There is a growing body of literature that examines resident perceptions towards the hosting of events (Chien, Ritchie, Shipway, \& Henderson, 2011; Karadakis \& Kaplanidou, 2012; Kim \& Petrick, 2005; B. W. Ritchie, Shipway, \& Chien, 2010; B. W. Ritchie, Shipway, \& Cleeve, 2009). Waitt (2003) highlights that residents constantly reevaluate their perception of the event within the social setting and thus their perceptions are not static. Ritchie and colleagues (2009) have confirmed this through publishing multiple articles from a longitudinal study on perceptions of the 2012 London Olympics, which tracks changes in resident perceptions over time (Chien et al., 2011; B. W. Ritchie et al., 2010). Being aware of resident perceptions can allow event managers to develop strategies to alleviate potential negative impacts.

The majority of research on resident perceptions has, however, typically focused on those living in the host city (B. W. Ritchie \& Smith, 1991). However, a few studies have begun to examine the perceptions of residents from non-host cities (Deccio \& Bagloglu, 2002; Karadakis \& Kaplanidou, 2012; B. W. Ritchie et al., 2009). Research has suggested that resident perceptions may differ depending on proximity to the event (Cegielski \& Mules, 2002; Fredline, 2004; B. W. Ritchie \& Inkari, 2006; B. W. Ritchie et al., 2009). For example, B. W. Ritchie et al. (2009) found that those who lived closer to the actual event venues were less supportive of the event than those who lived further away, perhaps because of the perceived disruption to their quality of life during event time. Similarly, Cegielski and Mules (2002) suggest that those who lived further away had more positive perceptions of the impact of the events than those who lived closer. As event organizers and state departments are encouraged to increase the flow of benefits to other regions of the 
state and country outside of the host city, it is useful to understand the perceptions of residents in nonhost communities and examine strategies that can engage these non-host residents in the event.

Deccio and Baloglu (2002) examined the perceptions of individuals who lived 250 miles away in Garfield County, Utah towards the 2002 Winter Olympics in Salt Lake City. Specifically, they examined resident' perceptions of the spillover effects of the event. They found that while some residents believed that their local community would benefit from the Games, most did not. B. W. Ritchie et al (2009) examined resident perceptions of the London 2012 Olympic and Paralympic Games. They conducted research in the cities of Weymouth and Portland in England. Although these cities are technically outside of the central Games district of London, and thus allow the authors to claim non-host city status, the two cities did in fact host the Sailing and Windsurfing events during the Games. They found residents had high levels of support for hosting the sailing events in the city before the event.

Karadakis and Kaplanidou (2012) examined the legacy perceptions of residents living in both a host (Vancouver) and non-host city (Ottawa) towards the 2010 Vancouver Winter Olympic Games. They found that residents in the non-host community rated the economic, tourism, environment, and knowledge development legacy benefits slightly higher than residents of the host community. They suggested that this effect could be attributed to an increase in awareness of the negative tourism impacts among residents in the host community as the host community was more likely to experience direct effects of the event.

The research on resident perceptions has predominantly focused on the outcomes in hindsight, rather than considering how an event can be strategically leveraged in advance of the actual event (Chalip, 2004, 2006). A more strategic approach can encourage change in social agendas (Chalip, 2006; Kellett et al., 2008). Hence, it is useful to understand how an event can be leveraged in a non-host community. The first research question of this study asks: what are Townsville resident perceptions of the Gold Coast hosting the 2018 Commonwealth Games? This question is asked with the view of devising strategies that can be effectively implemented within that community.

\section{Leveraging Events for Benefits} to Regional Communities

Given that public monies spent on events are often from state and federal sources one would expect the effects of the event to be purposefully directed both within and outside of the host city (Chalip, 2004). The majority of research on strategically leveraging events has typically focused on the host destination (Kellett et al., 2008). However, we know little about how regional communities can capitalize on large-scale sport events hosted in the nation. Limited studies have examined the impact of the events outside of the host city (Kellett et al., 2008; O’Brien \& Gardiner, 2006). These studies have highlighted that the distribution of benefits can be expanded to non-host cities through strategic leveraging.

O’Brien and Gardiner (2006) examined how three regional communities capitalized on Sydney hosting the 2000 Olympic Games through organizing pre-Games training camps for competing nations. In preparation for international sporting competition, national teams and athletes typically train in regional cities to acclimatize to the environment before the event (Gardiner \& Chalip, 2006). Thus, cities can take advantage of attracting and setting up training camps for visiting nations that can result in additional tourism to the region, increased media coverage to the city, and relationships for sport, business, and tourism development (Gardiner \& Chalip, 2006). O’Brien and Gardiner (2006) note that some regional communities were proactive in their attempts to leverage an event of national significance in their regional community. For example, in 1993, shortly after it was announced that Sydney would host the 2000 Olympics, a committee was formed for the purpose of leveraging the event in multiple states and cities including at the state level (e.g., Australian Capital Territory), and on the regional level (e.g., Gold Coast). O’Brien and Gardiner note that the successful cities were those that developed a long-term plan to create relationships through regional sport, business, and tourism development.

In another example of regional communities capitalizing on an event being hosted by the nation, Kellett et al. (2008) examined the event programming including the provision of live sites, cultural programming and activities, and actual events from 
the 2006 Melbourne Commonwealth Games sport program in two regional communities. Specifically, their study examined two regional communities that participated in the Adopt a Second Team program where municipalities in Victoria were encouraged to adopt a team from one of the 71 nations who participated in the Games. Under this program, each city was given the flexibility to plan and implement activities around their adopted team as they saw fit. Consistent with what has previously been suggested by Chalip (2004), Kellett et al. (2008) found the city that strategically leveraged the event obtained benefits, whereas the city that participated in the same program, but did not actively leverage the program, did not maximize the benefits to the community. Thus, this research highlights the necessity to strategically plan and leverage assets in order to capitalize on the event.

Beesley and Chalip (2011) suggest that there are four primary initiatives to produce outcomes for non-host destinations when leveraging events. These include: “attracting pre-event training, staging preliminary competitions, hosting lead-in activities, and creating activities that foster event business" (p. 325). Note that all of these strategies extend benefits to the actual site of the regional communities. In other words, these strategies focus on bringing activity and direct benefits into the regional community through generating economic benefit via tourism, or by providing programming within the local community rather than encouraging regional communities to be involved in the main event in the host city. To extend this line of research, this study not only examines the perceptions of residents from a nonhost city towards the event, but also examines resident perceptions towards volunteering at the event that would occur in the host city. This raises research question 2: what are Townsville resident perceptions of volunteering for the 2018 Commonwealth Games on the Gold Coast? Because prospective volunteers from this regional community would have to travel to the event, the research on event volunteer tourism is reviewed next.

\section{Event Volunteer Tourism}

Volunteers are critical to the successful delivery of many events in providing significant amounts of unpaid labor (Green \& Chalip, 2004; Moreno,
Moragas, \& Paniagua, 2000). This is especially true as events grow in size and scope (Nichols \& Ralston, 2012). Larger and more unique events attract more diverse volunteer profiles (Chalip, 2000; MacAloon, 2000) and also attempt to recruit and retain a substantial number of volunteers from the resident population (Cuskelly et al., 2006). Research has suggested the benefits of cultivating a volunteer base in a community may last long after the event and assist in building event and tourism volunteer resources in the future (Fairley, Gardiner, \& Filo, 2016; Fairley, Green, O’Brien, \& Chalip, 2015; Ralston, Lumsdon, \& Downward, 2005). Thus, leaving a legacy of volunteering in a community may be a stated outcome of the event organizers (Doherty, 2009; Downward \& Ralston, 2006; Fairley et al., 2016).

Although not looking at tourism, Downward and Ralston (2005) noted that events have the ability to draw volunteers from outside of the host region. This phenomenon has also been noted on an international level with approximately one third of individuals who expressed an interest to volunteer at the Athens Olympics residing outside of Greece. Fairley et al. (2007) followed a group of volunteers from Australia who traveled to volunteer at the 2004 Athens Olympic Games. They found that nostalgia, camaraderie and friendship, Olympic connection, and sharing and recognition of expertise were key in the decision to travel to volunteer at the Athens Olympics Games. Interestingly, tourism was not a primary motive even though individuals had to travel from Australia to Greece in order to perform their volunteer role.

The study conducted by Fairley et al. (2007) illustrates an organic volunteer legacy where volunteers themselves formed a group in order to continue and extend the camaraderie and excitement established at the 2000 Sydney Olympic Games. In other words, the volunteer tourism generated was not related to any active event leverage strategy. Similarly, Fairley et al. (2016) found that an organic volunteer legacy existed 10 years after the 2000 Sydney Olympic Games. They found that as a result of volunteering at the Olympics volunteers started or rekindled a volunteer career, developed a unique set of skills and abilities, and generated nostalgia for the atmosphere of the Games. Further, Fairley et al. (2015) note that the volunteer legacy 
is not limited to the individuals who volunteer during Games time, but extends to individuals who volunteer in the lead up to the event. These volunteers are known as planning or pioneer volunteers. However, research on event leverage including that reviewed on regional communities above highlights the need to devise specific strategies in order to fully capitalize on the event (Chalip, 2004, 2006; Kellett et al., 2008). Accordingly, eliciting perceptions from regional community residents as prospective event volunteers could inform strategy development for leveraging the event.

This study examines regional community (i.e., Townsville) resident perceptions of a mega-event (i.e., The Commonwealth Games) to be held elsewhere in the state (i.e., Gold Coast). In addition, the current research investigates regional community residents' perceptions of volunteering for this mega-event within the host destination. Specifically, two research questions are advanced:

RQ1: What are Townsville resident perceptions of the Gold Coast hosting the 2018 Commonwealth Games?

RQ2: What are Townsville resident perceptions of volunteering for the 2018 Commonwealth Games on the Gold Coast?

\section{Method}

\section{Research Context}

The 2018 Gold Coast Commonwealth Games. The Commonwealth Games is a multisport megaevent that is held every 4 years in different countries. Competing countries come from the Commonwealth, which is an association of independent sovereign states that represents approximately 30\% of the world's population (Commonwealth Games Federation, 2013). The Gold Coast, Queensland, Australia will be hosting the 2018 Commonwealth Games. The event includes more than 6,500 athletes and officials from 70 Commonwealth nations. Federal, state, and local government sources all provide financial assistance for the event. The Queensland State Premier at the time stated: "These Commonwealth Games bring tangible and intangible benefits to the Gold Coast and all of Queensland that go well beyond the staging of events" (Department of for Tourism, Major Events, Small Business and the Commonwealth Games, 2015). The significance of the event is acknowledged in the event itself being added to one of the state Ministerial Portfolios. Specifically, instead of just being delegated to an existing portfolio, the Ministerial Department was restructured and is now titled the Department of Tourism Major Events, Small Business, and the Commonwealth Games.

The Commonwealth Games will utilize 15,000 volunteers in order to successfully run the event. This is consistent with the number of volunteers used at the 2014 Glasgow Commonwealth Games. The Director of Legacy and Policy at the Office of Commonwealth Games Coordination stated in a personal correspondence with two of the authors that one way to engage regional communities could be through volunteerism (personal communication, October, 2013). One community that was suggested as a potential target was Townsville, Queensland (personal communication, October, 2013). The city has the highest population density of any city within the state, but is outside of the southeast Queensland region where the event is held.

Townsville, Queensland. Townsville is located on the coast of northeast Queensland approximately 1,400 km northwest of Brisbane with a population of approximately 175,000. Townsville is considered a regional community. According to the Australian Bureau of Statistics (ABS, 2013) approximately $16.7 \%$ of the Townsville population had participated in voluntary work through an organization or group within the last 12 months. Townsville was chosen as it is the largest urban city in Northern Queensland and, as noted above, had been identified by the Gold Coast Commonwealth Games Committee as a region from which to draw volunteers (personal communication, October, 2013). Thus, the current research positions Townsville as a sizeable community and volunteer base that could potentially be engaged in the 2018 Commonwealth Games.

\section{Instruments}

To gain an understanding of the perceptions of regional residents towards the Commonwealth 
Games, as well as perceptions towards the activity of volunteering at the Games, this research utilized an online survey as well as focus groups and interviews. A snowball sampling technique was employed with the survey being distributed through a contact at Volunteering North Queensland and also through a university located in Townsville. The survey included questions about past, current, and future volunteering, and standard demographic measures. Further, the survey sought opinions about the likelihood of traveling to the Commonwealth Games to volunteer, and facilitators or inhibitors that would stand in the way. Examples of open ended questions are: "If you were given the opportunity to volunteer at the 2018 Commonwealth Games on the Gold Coast, what would be your primary considerations of whether to attend?" and "Is there anything that the Commonwealth Games could do to facilitate you volunteering at the Commonwealth Games?” Additionally, the survey was used as a means of soliciting focus group and interview participants in which they were provided an opportunity to provide more in-depth responses.

A series of six focus groups and four interviews were conducted. The focus groups each consisted of five participants and provided a group dynamic that facilitated the brainstorming of perceptions among multiple respondents through a discussion of their thoughts and feelings about a product or service (i.e., 2018 Commonwealth Games) (Krueger \& Casey, 2002). A series of semistructured questions were used in both the focus groups and interviews to guide an open discussion that sought to glean individual's thoughts and experience in volunteering in general, perceptions of the 2018 Commonwealth Games, and attitudes towards volunteering for the event. The questions included: "What are your perceptions of the Gold Coast hosting the 2018 Commonwealth Games?" "Do you think the Townsville community feels connected to the Gold Coast Commonwealth Games?" “The Gold Coast is hosting the 2018 Commonwealth Games, have you considered volunteering at this event? Why/why not?" and "What do you see as the big barriers to volunteering at the Commonwealth Games?” Focus groups and interviews ranged between 35-90 min. The focus groups and interviews were audio recorded and transcribed verbatim. No incentives were provided.

\section{Data Analysis}

Focus groups, interviews, and open-ended survey responses were used to understand Townsville residents' perceptions of the 2018 Gold Coast Commonwealth Games, and their perceptions towards volunteering at the Commonwealth Games on the Gold Coast. The data were thematically coded to extract key themes and meanings through pattern recognition (Attride-Stirling, 2001). An inductive process was used to identify themes through a process of open, axial, and selective coding (Glaser \& Strauss, 1967). Open coding was utilized to identify overarching themes relating to resident perceptions of the 2018 Gold Coast Commonwealth Games, and the positives and negatives of volunteering at the Commonwealth Games. Through the use of axial coding, codes were refined and relationships among them were identified. Next, selective coding was utilized to further refine the relationships among the themes. The coding identified two interrelated themes pertaining to resident perceptions towards the 2018 Commonwealth Games: rivalry between the host and non-host community, and perceived lack of benefit to the host city. Further, six themes emerged that explained Townsville resident perceptions of volunteering at the Gold Coast Commonwealth Games. These themes included inhibitors such as travel constraints, and lack of awareness; means through which to facilitate volunteer travel through the use of volunteer packages; and benefits such as national pride, once in a lifetime experience, and meeting new people from overseas.

\section{Results}

\section{Research Question 1}

In addressing the question, "what are Townsville resident perceptions of the Gold Coast hosting the 2018 Commonwealth Games?” two themes emerged: rivalry between the host and non-host regional community, and perceived lack of benefit to the non-host city. Quotations underscoring each theme are highlighted below.

Rivalry Between the Host and Non-Host Regional Community. In discussing their perceptions of the Gold Coast hosting the 2018 Commonwealth 
Games, the notion of a rivalry emerged. Townsville residents consistently pointed to a rivalry between the host and non-host community, and by extension, the two regions within the stateNorth Queensland and Southeast Queensland. One respondent put it this way: "Brisbane and the Gold Coast would probably just want to hog it all to themselves. . . . I've been down to Brisbane and the rift is something shocking” (Jon). A second respondent further elaborated on the rift between the two regions, and positioned the event as a consideration within this rift: "Everyone from NQ [North Queensland] hates people from Southeast Queensland. ... They're not bringing anything up here for us so you know there is your problem" (Paula).

Beyond detailing a perceived rivalry between Townsville and the Gold Coast, the above quote introduces the notion that Townsville residents may not see direct benefits to their community as a result of the Gold Coast hosting the event. This introduces the second theme: perceived lack of benefit.

Perceived Lack of Benefit. Respondents believed that there would be a lack of benefit to the Townsville residents from the Gold Coast hosting the Commonwealth Games. For example, one respondent described this as follows:

Generally, events, when held in Queensland, are always focused near major cities. The fact that the Games will be mostly in the Gold Coast means that the Gold Coast and Brisbane will receive, yet again, all the publicity. . . . I don't believe Townsville will really feel the advantages of such an event. (Tony)

Responses like this were particularly common: "I think that a lot of the Townsville community simply sees it as sucking the money for infrastructure into the southern corner [e.g., Brisbane and the Gold Coast]” (Mary). Another respondent stated:

There is no benefit because it has no impact. We do not get any funding to benefit our local community. We see copious amount of funding for the southeast corner of the state of Queensland. There is only cut backs for regional areas. Or if we need anything, we have to raise the funds locally. (Tristan)
Note from the above quote that it is not simply that the southeastern cities are receiving the funding and support, but that it is seen to be at the expense of the Townsville region. The residents feel their community is neglected by the state government and that clear preference is given to the southern part of the state. Further, the residents do not feel that the event, albeit of national and international significance, will benefit their community directly. This highlights that the Townsville residents may not see any benefit to their community directly through the Gold Coast's hosting of the Commonwealth Games. The perceived lack of benefits may then impact an individual's willingness to travel to the Games to volunteer as that may be seen as helping out one's rival. The perceptions of volunteering for the event are showcased next.

\section{Research Question 2}

In exploring Townsville resident perceptions of volunteering for the 2018 Commonwealth Games hosted on the Gold Coast, six themes emerged. Specifically, these themes included inhibitors such as travel constraints, and lack of awareness; means through which to facilitate volunteer travel through the use of volunteer packages; and benefits such as national pride, once in a lifetime experience, and meeting new people from overseas. Each of these themes is outlined below alongside supporting quotations.

Travel Constraints. For those who were interested in volunteering for the Games, they highlighted that the interrelated factors of distance between Townsville and the Gold Coast, along with the time and cost to travel would all be potential inhibitors. One respondent offered:

I'd definitely volunteer for that because I enjoy the atmosphere that comes with the Commonwealth and Olympic Games. ... . So if it was up here I'd go to it, but being so far away I can’t see myself actually doing that [volunteering] because for one it's on the Gold Coast and it's too far away. . . . You have to pay travel fees, accommodation fees, and food to be there. So it's more of I want to do it, I just can't do it at the moment. . . . Also the time. I wouldn't have any time because I'd be just missing out on my work. (Edward) 
Note that while highlighting the combination of factors that would inhibit one from volunteering such as travel, accommodation, and food, existing commitments such as work were also raised.

Similarly, others raised concern with being away from family commitments as demonstrated by the following quote:

Unfortunately, you've got to get on a plane to get there and I can't be away for too long because of family commitments, but if you are required to be there for the length of the Games, what is it 14 days or whatever, it's too far away for me to be away from home. Even if they have a roster and I need to be there for $4 \mathrm{~h} \mathrm{I}$ am still paying accommodation for the day. (Antonella)

The above quote highlights that with the significant expense and distance traveled, consideration must be given to the length of volunteer responsibilities. The actual duration of the event is 12 days, however 12 days of volunteering would provide significant expense and would also require considerable time away from work and/or family commitments. On the other hand, the volunteer opportunities should be sufficient so that individuals feel that their contribution is worth the expense of travel as can be seen in the above quote. This is further highlighted in the following quote:

It takes so long to get there. You have a day of travel each side. You can't just pop down for a day. You go down for the very least a long weekend. You can't just pop down and help out for the morning, which is what a lot of things are like a church event or even umpiring at a carnival. ... You can't just do the morning or whatever having to go all the way down to the Gold Coast. (Sasha)

Others further highlighted that travel-related prices including hotel and accommodation costs are typically raised around the time of events:

If you're living there [on the Gold Coast] it's okay because if you're volunteering you're not wasting as much, it's not possibly as much money. But from Townsville you've got to get flights and then you've got to stay there how many nights you're volunteering - so if it's five you have to get a hotel for five nights . . . and at that time all the hotels bump up prices because of people all over the world are coming. (Harry)
In summary, the interrelated issues of distance, time, and cost were all key factors that could inhibit Townsville residents from traveling to volunteer at the Commonwealth Games. The time that individuals would need to be away would influence cost. Negative perceptions concerning the value of the volunteer experience were uncovered within the next theme to emerge: lack of awareness.

Lack of Awareness. Focus group participants and interviewees were largely unaware of opportunities to volunteer at the 2018 Commonwealth Games on the Gold Coast and had therefore never considered it. One respondent put it this way: “I haven't [thought about volunteering] because I wasn't aware of it. I knew the Games were happening I just didn’t know people could volunteer for that” (Adele). Another respondent put it this way: "It's actually not advertised enough either-the only time I have volunteered is when I've been asked" (Joseph). Further, information about the types of volunteer opportunities needs to be provided as perceptions of volunteering at the Games may be insufficient as displayed in the following quote:

I don't really know what you would volunteer for apart from picking up rubbish. I also think people would not volunteer because they would not know what type of work they are in for. If you just said come and volunteer at the Commonwealth Games they would probably think straight away I am going to be picking up rubbish. (Joseph)

Beyond the roles on offer through volunteering, respondents described perceptions concerning the need for informed, coordinated, and subsidized volunteer programs within the event. This notion underscores the next theme: volunteer packages.

Volunteer Packages. Given the considerable amount of resources that individuals would need to forgo in order to travel to the Gold Coast to volunteer at the Commonwealth Games, respondents suggested that volunteer programs directed at them should be informed, coordinated, and subsidized. It was also suggested that this information should include details on all travel-related variables such as transport, accommodation, and food, and have a comprehensive description of what is and isn't 
included for the volunteer. One respondent put it this way:

Information and communication that includes travel, accommodation you know all these things, you know a person that wants to go down they would want to know if they need food or don't need food, are they accommodated or not accommodation, when they are actually going to be there, is there going to be a roster or so I have to be there $24 / 7$. There is just not enough information out there. (Obie)

Note from the above quote that specific information about the roster is also necessary as individuals can then plan around their duties if they wanted to participate in any other activities while in the host destination. Further, respondents highlighted that they believed some of their expenses should be subsidized as shown in the following quote: "Because you are offering them your free help you'd expect to get something in the way of consideration for how much you're spending to help them for free” (Elise). Another respondent put it this way:

\footnotetext{
I think something needs to be subsidized because food and drink at those events is really expensive. You don't want to be there for $8 \mathrm{~h}$ and have to be told you can't take water and then you have to buy four or five liters of water because it's really hot ... if I have to pay for my accommodation, all of my food or my flight hand-in-hand it's a lot harder than just paying for my flight and some of my food. If some of that cost can be subsidized from a financial point of view it's a lot more realistic. (Sally)
}

It was consistent among respondents that while they believed that their expenses should be subsidized, at least in part, they were happy to pay for their airfare. Further, individuals also sought some acknowledgment for their volunteering in the form of a certificate: "If you just get something to say, like a piece of paper, or you just get a certificate saying that you were there and you did this, this, and this. Then that would probably be beneficial” (Jonah). This again highlights that detailed information should be provided to potential volunteers about both their volunteer roles and what it includes. Additionally, providing volunteers with something tangible, such as a certificate, may further reward their involvement in the activity.
Individuals also highlighted that they would be more willing to travel if they could travel in groups with other Townsville residents. This was attributed to a number of factors including knowing other people as described in the following quote: "It's a matter of knowing people who are going or not. That would influence my decision greatly" (Dave). Another respondent put it this way: "Well it would be pretty boring going by yourself. So pretty much that would be a big barrier" (Justin). Further, individuals highlighted that traveling in a group would provide a safety net for individuals who would otherwise travel alone:

If people go down in groups I think it's more of a safety in numbers kind of thing. Everybody who would go down there would go down there with the thought that they're going to meet a heap of new people, but it's more just the fact they're getting down there and having that safety net that there are going to be other people that you know already. There would probably be an incentive to go. (Danielle)

In describing perceptions of volunteering for the 2018 Commonwealth Games, respondents did highlight a number of positive outcomes or attributes that could be experienced. Specifically, respondents described volunteering for the Commonwealth Games as an opportunity to celebrate national pride, a once in a lifetime experience, and an opportunity to meet new people from overseas. These three perceptions reflect the final three themes uncovered.

National Pride. Individuals indicated that national pride would be one reason why they would consider volunteering at the Commonwealth Games. When asked if individuals would consider traveling to the Games to volunteer, one respondent put it this way: "I would answer yes on that because I'm an Aussie and we are connected to the Commonwealth Games . . . in a way, national pride because it shows we can do a really good job here, look at the event” (Leidy). Individuals felt connected to the Commonwealth Games through Australia's participation in the Games, and they wanted to ensure that the event was delivered well. Another respondent put it this way: 
Yes, I would love to help with volunteering because you are there to help the sporting people that they practice so much just to get there for that day and even if they don't get anywhere at the competition it's still an achievement for them to be there so yes I would be very proud to help them out. ... I would feel really proud to be there. The experience to meet all those great athletes, to know that I did achieve something you know to know I was there running or helping them with the swimming competition. I would feel proud to represent Australia and make sure that everything runs smoothly so when those people go back to their countries they can say the volunteers were great. (Rosetta)

The above quote depicts the willingness to help the nation, but also further highlights the extension of national identity to the athletes that were representing the nation, and the willingness to assist through volunteering at the event. There is also reference to meeting the national level athletes. These experiences portray volunteering as a once in a lifetime experience, the next theme to emerge.

Once in a Lifetime Experience. Many respondents highlighted that volunteering at the Commonwealth Games would likely be a once in a lifetime opportunity. Respondents were attracted to potential volunteer opportunities because of the uniqueness and rarity. One individual put it this way:

There are a lot of very sporty people around here and there that will be probably willing to travel because it's like I said it's an event that happens every 4 years and you might not get a chance to do it again. It's a once in a lifetime event. (Rosetta)

Another respondent put it this way: "I would love to volunteer for the Commonwealth Games because I always watch it on TV and it's an experience of a lifetime. ... I I would love to be in the atmosphere" (Carmel). Many of the respondents highlighted that they consistently follow the Commonwealth Games on television when it is on in other cities and countries. Thus, it is an event with which many people are familiar. Others suggested that the once in a lifetime nature of the event will allow individuals to become involved in unique experiences:
You're gaining access to the site, you know you're probably in the site of an event space that wasn't there before, probably not going to be there after so it's a once in a lifetime thing ... you could possibly do something that you haven't done before as a volunteer. (Jane)

The above quote highlights that individuals who volunteer could gain access to sites and experiences that are not commonly available. Thus, being involved with a unique atmosphere encompassing a once in a lifetime event is a key factor that may encourage regional residents to travel to volunteer at the Commonwealth Games.

Meeting new People From Other Nations. Camaraderie and meeting new people, especially those from overseas, was seen as a key potential benefit for volunteering at the Commonwealth Games. One respondent advanced:

You could also have relationships you can make with people whether they come from overseas. It's a lot about people ... the relationships would probably be the biggest one I would say and how you're building those relationships with people. (Jon)

\section{Another respondent put it this way:}

Just meeting a ton of new people internationally. You can just have a chat to anyone. You meet so many people and you get a lot of contacts ... not just for your CV or anything, but you can make new friends. Just meeting new people and meeting the athletes seems good, but just the experience being in an international event there's not too many opportunities like that. (Adrian)

Note that in the above quote, meeting new people was also suggested to result in contacts, even if those new contacts were purely social and not professional.

\section{Discussion}

The qualitative data collected in the current research uncovered a number of themes relevant to the literature on event and volunteer management. With regard to Townsville resident perceptions of the Gold Coast hosting the 2018 Commonwealth Games, two main findings were revealed. First, 
a rivalry existed between the non-host regional community (i.e., Townsville) and the host community (i.e., Gold Coast). This rivalry influenced Townsville resident attitudes towards the event. It has been suggested that resident support for an event is dependent upon the perceived benefits and costs derived from the event (Ap, 1992; Deccio \& Baloglu, 2002; Karadakis \& Kaplanidou, 2012). The results of this study have highlighted that underlying and preexisting relationships or rivalries between host and non-host cities may bias and/or significantly influence resident perceptions towards an event. The results of this study highlight a similar concern where a preexisting rivalry between two cities, and by extension two regions, significantly influenced how residents perceived the event and the potential impacts of the event on the non-host community. Although this study did not set out to examine the relationship between the two cities, the historical relationship clearly impacted the way that non-host residents viewed the event. Previous studies of the perceptions of non-host city residents have quantitatively measured perceptions of legacies of the event (Karadakis \& Kaplanidou, 2012), potential spillover effects (Deccio \& Bagloglu, 2002), and support for the event (B. W. Ritchie et al., 2009).

Second, there was a collective perceived lack of benefit to Townsville among residents towards the Gold Coast hosting the 2018 Commonwealth Games. Research has suggested that resident perceptions may differ based on proximity to the event and that those who lived closer to the event are less supportive than those who live further away because of the disruption to their lives (Cegielski \& Mules, 2002; B. W. Ritchie et al., 2009). Additionally, previous research has suggested that nonhost community residents perceived that there would be more economic, tourism, environment, and knowledge development benefits than those in the host city (Karadakis \& Kaplanidou, 2012). The results of this study suggest otherwise and are more consistent with the work of Deccio and Bagloglu (2002), who suggest that non-host city residents believe that there would be minimal benefit to their community. Further, the lack of perceived benefits to non-host community residents could be influenced or amplified by the inherent sense of rivalry or inequity between the two cities.
Six main findings were revealed through addressing Townsville resident perceptions of volunteering for the 2018 Commonwealth Games hosted on the Gold Coast. First, travel constraints related to time, costs, and distance were viewed as inhibitors. Second, a lack of awareness and understanding of volunteer opportunities that existed permeated the discussion. Third, Townsville residents believed that volunteer packages should be developed and delivered to facilitate volunteering. Fourth, volunteering for the 2018 Commonwealth Games was portrayed as an opportunity to exhibit national pride. Next, volunteering was also depicted as a once in a lifetime experience among perspective volunteers. Finally, Townsville residents did value the prospective opportunity to meet new people from overseas through volunteering.

Given that non-host city residents would have to travel in order to volunteer at the actual event, constraints such as distance, time, and cost were identified as key barriers to volunteer at the event. Further, these issues are not uncommon to volunteering at an event irrespective of distance traveled. For example, Elstad's (1996) study of volunteers at the 1994 Lillehammer Winter Games notes that the most common downside to volunteering was expenses for transportation and food, and workload in terms of having too little or too much to do. Similarly, Doherty (2009) identified task overload and underload, and personal inconvenience as potential costs or points of dissatisfaction among volunteers.

Lack of awareness of volunteer opportunities at the 2018 Commonwealth Games was a barrier for non-host city residents to volunteer. This is consistent with other research on volunteerism, which suggests that the most common reasons for not volunteering are because individuals are unaware of opportunities, or not provided with sufficient information (Sundeen, Raskoff, \& Garcia, 2007). Given that this research was conducted 4 years out from the event and before volunteer roles and positions had been finalized or advertised, a lack of awareness would be expected. However, it is useful to flag opportunities for the non-host city residents to get involved with the event well in advance so that individuals can contemplate and plan for the opportunity.

Non-host city resident sought volunteer provisions that were informed, well-coordinated, and believed that their travel expenses should be 
partially subsidized. Although there has been some debate in the literature over whether a degree of funding would exclude someone from being termed a "volunteer," it appears to be widely accepted that a subsidy within reason is acceptable (Fairley, Lee, Green, \& Kim, 2013; Handy, Cnann, Brudney, Ascoli, \& Meijs, 2000). Individuals expressed a desire to travel in a group to provide a sense of safety, comfort, and camaraderie. This is similar to previous research on event volunteer travel (Fairley et al., 2007), and is also consistent with other sport tourism research on sport fans (Fairley, 2003) and sport participants (Green \& Chalip, 1998).

Volunteer managers must consider the benefits that volunteers seek in order to design and implement effective volunteer recruitment and retention strategies (Green \& Chalip, 2004; Taylor, Doherty, \& McGraw, 2008). The benefits that were identified in this study were: national pride, a once in a lifetime opportunity, and meeting new people. National pride is similar to the concept of patriotism that Bang and Chelladurai (2009) have utilized in their volunteer motivation scale for international sport events (VMS-ISE). The uniqueness of the event and the opportunities to be involved in the event through volunteering provides a once in a lifetime opportunity, which was particularly attractive as individuals were familiar with the Commonwealth Games. Meeting new people is a commonly identified motive for volunteering (Elstad, 1996; Fairley et al., 2007; Green \& Chalip, 2004); however, the focus of meeting new people in this instance was focused on meeting people from other nations. This is consistent with research that suggests that megaevents can strengthen regional values and traditions and foster cultural understanding among both residents and visitors (Hall, 1989).

\section{Practical Implications}

The results highlight a number of practical implications for event and volunteer managers. Event managers and the governments that fund the events should be cognizant of the direction of tax dollars to the host city and region. The benefits that the event may bring to the wider state and nation should be emphasized to minimize any perception that benefits are contained to the host city. It may be useful to identify key stakeholders from the region to engage the region with the Commonwealth Games. This is particularly important given the apprehension with messages that come from outside of the region.

Awareness of volunteer opportunities should be promoted through marketing communications that include detailed information on the roles and responsibilities of volunteer positions while being mindful that the roles must be meaningful to justify travel to the event. The ability of the activity to create community cohesion, camaraderie, and friendship should be promoted. Previous research on resident perceptions of international events highlights that positive benefits to the community may include increased community pride, and a heightened national identity salience (Hall, 1989; Kim \& Petrick, 2005; Waitt, 2003). Hence, communications should show imagery and language that features national identity and in particular highlights how volunteer efforts can assist the performance of Australian athletes, along with how volunteering at the event provides a once in a lifetime opportunity in an event of international significance.

Attempts to simplify the travel process for potential volunteers should be made. This should include providing information about travel and accommodation options, and perhaps offering subsidies and incentives for volunteers to travel to the event. Just as group packages are provided for those traveling to watch or compete in sport events (Chalip \& McGuirty, 2004; Fairley, 2003), it may be useful to create packages for volunteers that include all elements of travel. Travel packages should be designed and provided at a discount rate in order to encourage individuals to see value in the packages. Information should provide sufficient detail so that volunteers are aware of what is and is not included when they are volunteering so that they know any costs upfront. In promoting the packages, it should be highlighted that individuals could travel in a group of residents in order to allow individuals to feel safe and secure while not traveling alone.

\section{Limitations}

Limitations of the current research are acknowledged. First, data were collected 4 years prior to the event taking place. Given that the 2018 Commonwealth Games represent a mega-event, a large 
portion of coordination and logistics were underway during the time of data collection. However, this relatively extensive timeframe in advance of the event may have influenced the results. In particular, the lack of awareness described by Townsville residents could be attributed to the fact that the event would not be taking place for an additional 4 years. Second, while Townsville provided a suitable environment to explore regional community resident perceptions of a mega-event, certain contextual aspects may impact the generalizability of findings. Specifically, the sheer distance between Townsville and the Gold Coast made it highly likely that travel constraints would emerge as a perception of volunteering for the event. Hence, data can be collected from other regional communities that are closer to the Gold Coast. With these limitations in mind, suggestions for future research are advanced.

\section{Future Directions}

A number of future studies can be initiated based upon the current research. First, residents continually reevaluate their perceptions of an event over time (Waitt, 2003). For example, research has suggested that residents may have a more extreme view towards the positives and negatives of the event before the actual event (Soutar \& McLeod, 1993). Although some research indicates that positive perceptions increase over time (J. R. B. Ritchie \& Lyons, 1990), others advance that the opposite is true and that negative issues may increase over time given negative press coverage (Kim \& Petrick, 2005; Mihalik \& Simonetta, 1999). It would therefore be useful to conduct longitudinal research to examine whether resident perceptions change over time and what forces are leading to those changes. This longitudinal data would then address concerns with the extended time period prior to the event inherent to the current study.

Second, while national pride and a once in a lifetime opportunity emerged as key variables in this study, there are few studies that have acknowledged these benefits in the current sport and event volunteering literature (e.g., Bang \& Chelladurai, 2009; Kemp, 2002). This is probably due to the fact that many studies on sport event volunteerism, especially those that have looked at mega-events, have utilized a laundry list of motives that have been adopted from measures from outside of the sport and mega-event context. More exploratory research is needed that explicitly examines why individuals volunteer based upon the type of event. This additional exploratory research can also utilize different communities to determine if regional community resident perceptions vary based upon event type and distance from the host city. Furthermore, future research can collect data from additional event stakeholders such as event organizers, volunteer managers, and sponsors to determine plans and strategy for engaging volunteers from regional communities.

\section{References}

Andersson, T. D., Rustad, A., \& Solberg, H. A. (2004). Local residents' monetary evaluation of sports events. Managing Leisure, 9, 145-158.

Ap, J. (1992). Residents perceptions on tourism impacts. Annals of Tourism Research, 19(4), 665-690.

Attride-Stirling, J. (2001). Thematic networks: An analytic tool for qualitative research. Qualitative Research, 1(3), 385-405.

Australian Bureau of Statistics. (2013). Census: For a bright future. 2011 Census QuickStats. Retrieved from http:// www.censusdata.abs.gov.au/census_services/getprod uct/census/2011/quickstat/LGA37010

Bang, H., \& Chelladurai, P. (2009). Development and validation of the volunteer motivations scale for international sporting events (VMS-ISE). International Journal of Sport Management and Marketing, 6(4), 332-350.

Beesley, L., \& Chalip, L. (2011). Seeking (and not seeking) to leverage mega-sport events in non-host destinations: The case of Shanghai and the Beijing Olympics. Journal of Sport \& Tourism, 16(4), 323-344.

Cegielski, M., \& Mules, T. (2002). Aspects of residents’ perceptions of the GMC 400: Canberra's V8 Supercar Race. Current Issues in Tourism, 5(1), 54-70.

Chalip, L. (2000). Sydney 2000: Volunteers and the organisation of the Olympic Games: Economic and formative aspects. In M. Moragas, A. Moreno, \& N. Puig (Eds.), Symposium on volunteers, global society and the Olympic movement (pp. 205-214). Lausanne, Switzerland: International Olympic Committee.

Chalip, L. (2004). Beyond impact: A general model for host community event leverage. In B. W. Ritchie \& D. Adair (Eds.), Sport tourism: Interrelationships, impacts and issues (pp. 226-252). Clevedon, UK: Channel View.

Chalip, L. (2006). Towards social leverage of sport events. Journal of Sport \& Tourism, 11(1), 109-127.

Chalip, L., \& McGuirty, J. (2004). Bundling sport events with the host destination. Journal of Sport Tourism, 9, 267-282.

Chien, P. M., Ritchie, B. W., Shipway, R., \& Henderson, H. (2011). I am having a dilemma: Factors affecting resident 
support of event development in the community. Journal of Travel Research, 51, 451-463.

Commonwealth Games Federation. (2013). Past Commonwealth Games. Retrieved from http://www.thecgf.com/ games/games_index.asp

Cuskelly, G., Hoye, R., \& Auld, C. (2006). Working with volunteers in sport. London: Routledge.

Daniels, M. J. (2007). Central place theory and sport tourism impacts. Annals of Tourism Research, 34, 332-347.

Deccio, C., \& Baloglu, S. (2002). Non-host community resident reactions to the 2002 Winter Olympics: The spillover impacts. Journal of Travel Research, 41, 46-56.

Department for Tourism, Major Events, Small Business and the Commonwealth Games. (2015). Embracing our Games Legacy: Queensland's legacy for the Gold Coast 2018 Commonwealth Games. Retrieved from http://www.embra cing2018.com/icms_docs/178343_Queenslands_legacy_ for_the_Gold_Coast_2018_Commonwealth_Games.pdf

Doherty, A. (2009). The volunteer legacy of a major sport event. Journal of Policy Research in Tourism, Leisure, and Events, 1(3), 185-207.

Downward, P. M., \& Ralston, R. (2005). Volunteer motivation and expectations prior to the XVII Commonwealth Games in Manchester, UK. Tourism and Hospitality Planning and Development, 2(1), 17-26.

Downward, P. M., \& Ralston, R. (2006). The sports development potential of sports event volunteering: Insights from the XVII Manchester Commonwealth Games. European Sport Management Quarterly, 6, 333-351.

Elstad, B. (1996). Volunteer perceptions of learning and satisfaction in a mega-event: The case study of the XVII Olympic Winter Games in Lillehammer. Festival Management and Event Tourism, 4, 75-83.

Fairley, S. (2003). In search of relived social experience: Group-based nostalgia sport tourism. Journal of Sport Management, 17, 284-304.

Fairley, S., Gardiner, S., \& Filo, K. (2016). The spirit lives on: The legacy of volunteering at the 2000 Sydney Olympic Games. Event Management, 20(2), 201-215.

Fairley, S., Green, B. C., O’Brien, D., \& Chalip, L. (2015). Pioneer volunteers: The role identity of continuous volunteers at sport events. Journal of Sport \& Tourism, 19(3), 233-255.

Fairley, S., Kellett, P., \& Green, B. C. (2007). Volunteering abroad: Motives for travel to volunteer at the Athens Olympic Games. Journal of Sport Management, 21(1), 41-57.

Fairley, S., Lee, Y., Green, B. C., \& Kim, M. (2013). Considering cultural influences in volunteer satisfaction and commitment. Event Management, 17, 337-348.

Fredline, E. (2004). Host community reactions to motorsports events: The perception of impact on quality of life. In B. Ritchie \& D. Adair (Eds.), Sport tourism: Interrelationships, impacts and issues (pp. 155-173). Clevedon, UK: Channel View Publications.

Fredline, E. (2005). Host and guest relations in sport tourism. Sport in Society, 8(2), 263-279.

Gardiner, S., \& Chalip, L. (2006). Leveraging a megaevent when not the host city: Lessons from pre-Olympic training. Gold Coast, Queensland: Cooperative Research Centre for Sustainable Tourism.

Glaser, B. G., \& Strauss, A. L. (1967). The discovery of grounded theory: Strategies for qualitative research. Chicago, IL: Aldine.

Gratton, C., Shibli, S., \& Coleman, R. (2005). Sport and economic regeneration in cities. Urban Studies, 42(5/6), 985-999.

Green, B. C., \& Chalip, L. (1998). Sport tourism as the celebration of subculture. Annals of Tourism Research, 25, 275-291.

Green, B. C., \& Chalip, L. (2004). Paths to volunteer commitment: Lessons from the Sydney Olympic Games. In R. Stebbins \& M. Graham (Eds), Volunteering as leisure/ leisure as volunteering: An international assessment (pp. 49-67). Wallingford, UK: CABI International.

Gursoy, D., \& Kendall, K. (2006). Hosting mega events: Modelling local's support. Annals of Tourism Research, 33, 603-623.

Hall, C. M. (1989). Hallmark tourist events: Analysis, definition, methodology and review. In G. J. Syme, B. J. Shaw, D. M. Fenton, \& W. S. Mueller (Eds.), The planning and evaluation of hallmark events (pp. 3-40). Sydney, Australia: Avebury.

Handy, F., Cnann, R. A., Brudney, J. L., Ascoli, U., \& Meijs, L. C. (2000). Public perception of "Who is a volunteer": An examination of the net-cost approach from a crosscultural perspective. Voluntas, 11(1), 45-65.

Jago, L., Chalip, L., Brown, G., Mules, T., \& Ali, S. (2003). Building events into destination branding: Insights from experts. Event Management, 8(1), 3-14.

Jeong, G., \& Faulkner, B. (1996). Residents' perceptions of mega event impacts: The Taejon International Exposition case. Festival Management and Event Tourism, 4, 3-14.

Jones, C. (2005). Major events, networks, and regional development. Regional Studies, 39, 185-195.

Kang, Y.-S., \& Perdue, R. (1994). Long-term impact of a megaevent on international tourism to the host country: A conceptual model and the case of the 1988 Seoul Olympics. Journal of International Consumer Marketing 6, 205-225.

Karadakis, K., \& Kaplanidou, K. (2012). Legacy perceptions among host and non-host Olympic Games residents: A longitudinal study of the 2010 Vancouver Olympic Games. European Sport Management Quarterly, 12(3), 243-264.

Kellett, P., Hede, A., \& Chalip, L. (2008). Social policy for sport events: Leveraging (relationships with) teams from other nations for community benefits. European Sport Management Quarterly, 8(2), 101-121.

Kemp, S. (2002). The hidden workforce: Volunteers' learning in the Olympics. Journal of European Industrial Training, 26, 109-116.

Kim, S., \& Morrison, A. (2005). Change of image of South Korea among foreign tourists after the 2002 FIFA World Cup. Tourism Management, 26, 233-247.

Kim, S., \& Petrick, J. (2005). Residents' perceptions on impact of the FIFA 2002 World Cup: The case of Seoul as a host city. Tourism Management, 26, 25-38. 
Krueger, R. A., \& Casey, M. A. (2002). Designing and conducting focus group interviews. In R. Krueger, M Casey, J. Donner, S. Kirsch, \& J Maack (Eds.), Social analysis, selected tools and techniques (pp. 4-23). Washington, DC: World Bank.

MacAloon, J. (2000) Volunteers, global society and the Olympic movement. In M. Moragas, A. Moreno, \& N. Puig (Eds.), Symposium on volunteers, global society and the Olympic movement (pp. 17-29). Lausanne, Switzerland: International Olympic Committee.

Mihalik, B. J., \& Simonetta, L. (1999). Host perceptions of the 1996 Summer Olympic Games-Year II. Festival Management and Event Tourism, 5, 9-19.

Misener, L., \& Mason, D. (2006). Creating community networks: Can sporting events offer meaningful sources of social capital? Managing Leisure, 11, 39-56.

Misener, L., \& Mason, D. (2008). Urban regimes and the sporting events agenda: A cross-national comparison of civic development strategies. Journal of Sport Management, 22, 603-627.

Moreno, A. B., de Moragas, M., \& Paniagua, R. (2000). The evolution of volunteers at the Olympic Games. In M. de Moragas, A. B. Moreno, \& N. Puig (Eds.), Volunteers, global society and the Olympic Movement (pp. 133-154). Lausanne, Switzerland: International Olympic Committee.

Mules, T. (1998). Taxpayer subsidies for major sporting events. Sport Management Review, 1, 25-43.

Nichols, G., \& Ralston, R. (2012). Lessons from the volunteering legacy of the 2002 Commonwealth Games. Urban Studies, 49(1), 169-184.

O’Brien, D., \& Gardiner, S. (2006). Creating sustainable mega event impacts: Networking and relationship development through pre-event training. Sport Management Review, 9, 25-47.

Preuss, H., \& Solberg, H. (2006). Attracting major sport events: The role of local residents. European Sport Management Quarterly, 6(4), 391-411.
Ralston, R., Lumsdom, L., \& Downward, P. M. (2005). The third force in events tourism: Volunteers at the XVII Commonwealth Games. Journal of Sustainable Tourism, 13(5), 504-519.

Ritchie, B. W., \& Inkari, M. (2006). Host community attitudes towards tourism and cultural tourism development: The case of the Lewes District, Southern England. International Journal of Tourism Research, 8, 27-44.

Ritchie, B. W., Shipway, R., \& Chien, P. M. (2010). The role of the media in influencing residents' support for the 2012 Olympic Games. International Journal of Event and Festival Management, 1(3), 202-219.

Ritchie, B. W., Shipway, R., \& Cleeve, B. (2009). Resident perceptions of mega-sporting events: A non-host city perspective of the 2012 London Olympic Games. Journal of Sport \& Tourism, 14(2-3), 143-167.

Ritchie, B. W., \& Smith, B. H. (1991). The impact of a mega-event on host region awareness: A longitudinal study. Journal of Travel Research, 30(1), 3-10.

Ritchie, J. R. B., \& Lyons, M. (1990), Olympulse VI: A post-event assessment of resident reaction to the XVth Olympic Winter Games. Journal of Travel Research, 28(3), 14-23.

Soutar, G. N., \& McLeod, P. B. (1993). Residents’ perceptions on impact of the America's Cup. Annals of Tourism Research, 30, 571-582.

Sundeen, R. A., Raskoff, S. A., \& Garcia, M. C. (2007). Differences in perceived barriers to volunteering to formal organizations lack of time versus lack of interest. Nonprofit Management and Leadership, 17(3), 279-300.

Taylor, T., Doherty, A., \& McGraw, P. (2008). Managing people in sport organisations: A strategic human resource management perspective. Boston, MA: ButterworthHeinemann.

Waitt, G. (2003). Social impacts of the Sydney Olympics. Annals of Tourism Research, 30(1), 194-215. 